\title{
Ventilatory Function in Subjects with Childhood Asthma who have Become Symptom Free
}

\author{
MARGARET I. BLACKHALL \\ From Institute of Child Health, University of Liverpool, Alder Hey Children's Hospital, Liverpool
}

\begin{abstract}
Blackhall, M. I. (1970). Archives of Disease in Childhood, 45, 363. Ventilatory function in subjects with childhood asthma who have become symptom free. Ventilatory function was studied in 12 males who suffered from asthma in childhood, but who had been free of symptoms for an average period of 11 years. Though resting levels of $\mathrm{FEV}_{1}$ and the $\mathrm{FEV}_{1} / \mathrm{FVC}$ ratio were in most cases normal, an abnormal degree of bronchial lability was found in 7 subjects. An increase in RV was noted in the majority of subjects.
\end{abstract}

The paediatrician who looks after children with asthma is clearly concerned with the long-term prognosis, as it is one of the commonest questions asked by parents. There is considerable evidence that the severe childhood asthmatic tends to continue to suffer from attacks in adult life (Unger, Unger, and Wolf, 1952; Ogilvie, 1962), but it is the clinical impression that the milder the asthma the more likely it is to disappear during adolescence.

Follow-up studies of subjects with childhood asthma indicate that a variable, but considerable, number become symptom free (Bullen, 1929; Rackemann and Edwards, 1952; Ryssing and Flensborg, 1963; Barr and Logan, 1964; Buffum and Settipane, 1966). Yet many subjects who have had an appreciable period of freedom from symptoms experience a recurrence of asthma (Rackemann, 1932; Pearson, 1958; Ryssing, 1959), suggesting that an abnormal mechanism continues to operate even during the symptom-free interval. The finding of an abnormal degree of bronchial lability 4-10 years after cessation of symptoms by Jones and Jones (1966) supports this theory. The present study concerns mainly the milder group of asthmatics, and presents evidence of persisting abnormalities of ventilatory function after a prolonged period of freedom from symptoms.

\section{Subjects and Methods}

Twelve males with childhood asthma who had been free of symptoms for a minimum period of 2 years were studied. 3 had attended the asthma clinic at Alder Hey

Received 26 November 1969.
Children's Hospital, 5 were traced in the course of a follow-up study of adults who had attended the asthma clinic run by Professor C. A. Clarke, at the David Lewis Northern Hospital, Liverpool, 14-20 years previously, and the remaining 4 were members of the hospital staff.

Ventilatory studies. In all, the lability index was measured according to the method described by Jones (1966). The forced expiratory volume in one second $\left(F_{1}\right)$ and the forced vital capacity (FVC) were measured by means of a Lode spirometer, the average value of three attempts, after practice, being used. Exercise lasting 8 minutes was then carried out, with the subject running on a treadmill. The speed and slope of the treadmill were adjusted during the early part of the 8-minute period so that a level of exercise was obtained for each subject which could be continued uninterrupted for the remainder of the period without producing undue stress. $\mathrm{FEV}_{1}$ and $\mathrm{FVC}$ were measured in the post-exercise period at 2-minute intervals for 10 minutes, and the lowest value obtained was noted. Isoprenaline sulphate $1 \%$ was then given for 2 minutes, in divided doses, by a Wright's nebulizer with an air flow of $10 \mathrm{l} / \mathrm{min}$. This was followed immediately by brisk exercise on the treadmill for 1 minute. The $\mathrm{FEV}_{1}$ was then measured every minute for 5-6 minutes until a maximum value was reached. The lability index was then calculated according to the formula: Lability Index $=\left(\frac{\text { Fall in FEV }}{-\frac{\text { Rise in FEV }}{1}}-\frac{100}{\text { Predicted Normal FEV }}\right.$ where Fall in $\mathrm{FEV}_{1}=$ fall from resting level and where Rise in $\mathrm{FEV}_{1}=$ rise from resting level

The predicted normal $\mathrm{FEV}_{1}$ for subjects up to and including 18 years was obtained from the values given by Strang (1959), and for those over 18 years the formula of Cotes et al. (1966) was used. 
Lung volume and its subdivisions were measured using a closed-circuit helium-dilution technique (Gilson and Hugh-Jones, 1949). Preliminary studies were done to determine the accuracy of results using this method, duplicate estimations being made on 12 subjects. The mean change between first and second estimations was $-0.013 \pm 0.117$ in the case of the Functional Residual Capacity (FRC), $0.051 \pm 0.068$ for the Residual Volume (RV), and $-0.035 \pm 0.102$ for the Total Lung Capacity (TLC), indicating a satisfactory degree of repeatability.

A control series of normal subjects had lung volume estimations made and the data obtained from these were used to provide predicted normal values for the asthmatics. The results obtained from these normal subjects are reported elsewhere (Blackhall, 1969a).

Daily checks were made on the spirometers for leaks. All volumes were corrected to BTPS using the correction factors obtained from standard tables.

\section{Results}

It can be seen in Table I that all the subjects had originally had mild or moderate symptoms-none had severe asthma. The mean age of the group was $26 \cdot 2$ years (range 16-44 years) and the mean period of freedom from symptoms 10.6 years (range $2-32$ years).

TABLE I

Clinical Details of Subjects

\begin{tabular}{c|l|c|c}
\hline Case No. & $\begin{array}{c}\text { Severity of } \\
\text { Symptoms } \\
\text { in Childhood }\end{array}$ & $\begin{array}{c}\text { Present } \\
\text { Age } \\
\text { (yr.) }\end{array}$ & $\begin{array}{c}\text { Period of } \\
\text { Freedom from } \\
\text { Symptoms (yr.) }\end{array}$ \\
\hline 1 & Mild & 16 & 9 \\
2 & Moderate & 16 & 3 \\
3 & Moderate & 18 & 2 \\
4 & Moderate & 18 & 4 \\
5 & Moderate & 22 & 11 \\
6 & Moderate & 22 & 6 \\
7 & Mild & 24 & 10 \\
8 & Mild & 27 & 10 \\
9 & Moderate & 30 & 20 \\
10 & Mild & 33 & 32 \\
11 & Moderate & 44 & 4 \\
12 & Mild & 44 & $10 \cdot 6$ \\
\hline Mean & & $26 \cdot 2$ & $8 \cdot 3$ \\
SD & & $9 \cdot 5$ & \\
\hline
\end{tabular}

The mean observed $\mathrm{FEV}_{1}$ was 3.48 1., the predicted value being $3.93 \mathrm{l}$. (Table II). The difference between these values is not significant (see Table IV). The mean $\mathrm{FEV}_{1} / \mathrm{FVC}$ ratio (Table II) is also in the normal range. The mean lability index, however, was $16.8 \%$, which is somewhat higher than that obtained from most normal subjects, the majority of whom have values of $<15 \%$. A minority of normal subjects lies in the $15-20 \%$ range, in which a number of mild asthmatics are also found.
TABLE II

$F E V_{1}, F E V_{1} / F V C$, and Lability Index

\begin{tabular}{|c|c|c|c|c|}
\hline \multirow{2}{*}{ Case No. } & \multicolumn{2}{|c|}{$\mathrm{FEV}_{1}(\mathrm{~L})$} & \multirow{2}{*}{$\begin{array}{c}\mathrm{FEV}_{\mathbf{1}} / \\
\mathrm{FVC} \\
\%\end{array}$} & \multirow{2}{*}{$\begin{array}{c}\text { Lability } \\
\text { Index } \\
\%\end{array}$} \\
\hline & Observed & Predicted & & \\
\hline $\begin{array}{r}1 \\
2 \\
3 \\
4 \\
5 \\
6 \\
7 \\
8 \\
9 \\
10 \\
11 \\
12\end{array}$ & $\begin{array}{l}3 \cdot 22 \\
3 \cdot 19 \\
4 \cdot 88 \\
3 \cdot 26 \\
3 \cdot 02 \\
4 \cdot 09 \\
4 \cdot 86 \\
3 \cdot 11 \\
2 \cdot 84 \\
3 \cdot 22 \\
3 \cdot 09 \\
2 \cdot 98\end{array}$ & $\begin{array}{l}3 \cdot 21 \\
3 \cdot 86 \\
4 \cdot 70 \\
4 \cdot 20 \\
4 \cdot 03 \\
4 \cdot 30 \\
4 \cdot 52 \\
3 \cdot 71 \\
4 \cdot 05 \\
3 \cdot 96 \\
3 \cdot 25 \\
3 \cdot 39\end{array}$ & $\begin{array}{l}89 \\
80 \\
81 \\
76 \\
72 \\
72 \\
75 \\
75 \\
56 \\
73 \\
71 \\
67\end{array}$ & $\begin{array}{r}17 \\
7 \\
14 \\
28 \\
17 \\
13 \\
19 \\
17 \\
28 \\
8 \\
19 \\
14\end{array}$ \\
\hline $\begin{array}{l}\text { Mean } \\
\text { SD }\end{array}$ & $\begin{array}{l}3.48 \\
0.69\end{array}$ & $\begin{array}{l}3.93 \\
0.46\end{array}$ & $\begin{array}{r}73 \cdot 9 \\
7 \cdot 7\end{array}$ & $\begin{array}{r}16 \cdot 8 \\
6 \cdot 2\end{array}$ \\
\hline
\end{tabular}

It can be seen in Table II that though most subjects have good levels of $\mathrm{FEV}_{1}$ at rest, only 5 subjects have completely normal values for lability index (Cases 2, 3, 6, 10, and 12). Two subjects have high values (Cases 4 and 9), and the remaining 5 are in the $15-20 \%$ range.

The results of lung volume estimations are shown in Table III. The striking fact is that only 2 subjects have values of RV which are less than the predicted levels (Cases 4 and 11). The mean value for RV is 1.641 ., the predicted value being 1.331 . The difference between these means is significant (Table IV). The FRC and TLC are only marginally greater than the predicted values, and the differences are not significant.

Only one subject (Case 12) shows normal values for $\mathrm{FEV}_{1}, \mathrm{RV}$, and lability index.

\section{Discussion}

The finding of an abnormal degree of bronchial lability with normal levels of $\mathrm{FEV}_{1}$ and $\mathrm{FEV}_{1} / \mathrm{FVC}$ is in agreement with the results of Jones and Jones (1966). The mean lability index here is considerably lower than the value of $39 \%$ found by these workers. There is, however, a difference in the length of time during which no symptoms have occurred-6 years in the case of the 1966 study, 11 years in the present study. Possibly of even greater significance is the difference in the mean age of the groups-22 years in the first study, 26 years in the present one. We have reported elsewhere a decrease with age in the labile component of airways resistance in asthmatics (Blackhall, 1969b), and this may explain the lower values in this series. Yet the fact remains that an increased degree of lability still exists in over half these subjects, and 
TABLE III

Details of Lung Volume and its Subdivisions

\begin{tabular}{|c|c|c|c|c|c|c|}
\hline \multirow{2}{*}{ Case No. } & \multicolumn{2}{|c|}{ FRC (L) } & \multicolumn{2}{|c|}{ RV (L) } & \multicolumn{2}{|c|}{ TLC (L) } \\
\hline & Observed & Predicted & Observed & Predicted & Observed & Predicted \\
\hline $\begin{array}{r}1 \\
2 \\
3 \\
4 \\
5 \\
6 \\
7 \\
8 \\
9 \\
10 \\
11 \\
12\end{array}$ & $\begin{array}{l}2 \cdot 77 \\
2 \cdot 96 \\
3 \cdot 82 \\
2 \cdot 64 \\
3 \cdot 11 \\
3 \cdot 70 \\
4 \cdot 33 \\
2 \cdot 97 \\
3 \cdot 23 \\
2 \cdot 68 \\
2 \cdot 57 \\
3 \cdot 30\end{array}$ & $\begin{array}{l}2 \cdot 13 \\
2 \cdot 66 \\
3 \cdot 83 \\
2 \cdot 89 \\
2 \cdot 76 \\
3 \cdot 27 \\
3 \cdot 72 \\
2 \cdot 43 \\
3 \cdot 13 \\
2 \cdot 63 \\
2 \cdot 95 \\
3 \cdot 00\end{array}$ & $\begin{array}{l}1 \cdot 27 \\
1 \cdot 68 \\
2 \cdot 03 \\
1 \cdot 07 \\
1 \cdot 68 \\
1 \cdot 66 \\
2 \cdot 13 \\
1 \cdot 37 \\
1 \cdot 73 \\
2 \cdot 00 \\
1 \cdot 40 \\
1 \cdot 62\end{array}$ & $\begin{array}{l}0 \cdot 88 \\
1 \cdot 08 \\
1.64 \\
1 \cdot 29 \\
1 \cdot 23 \\
1 \cdot 43 \\
1 \cdot 60 \\
1 \cdot 10 \\
1 \cdot 36 \\
1 \cdot 30 \\
1 \cdot 48 \\
1 \cdot 58\end{array}$ & $\begin{array}{l}5 \cdot 34 \\
5 \cdot 78 \\
8 \cdot 50 \\
6 \cdot 03 \\
6 \cdot 01 \\
7 \cdot 60 \\
8 \cdot 36 \\
6 \cdot 16 \\
7 \cdot 47 \\
6 \cdot 85 \\
5 \cdot 90 \\
6 \cdot 69\end{array}$ & $\begin{array}{l}4 \cdot 95 \\
6 \cdot 16 \\
8 \cdot 03 \\
6 \cdot 42 \\
6 \cdot 30 \\
7 \cdot 18 \\
8 \cdot 01 \\
5 \cdot 88 \\
7 \cdot 16 \\
6 \cdot 47 \\
6 \cdot 46 \\
6 \cdot 71\end{array}$ \\
\hline $\begin{array}{l}\text { Mean } \\
\text { SD }\end{array}$ & $\begin{array}{l}3 \cdot 17 \\
0 \cdot 52\end{array}$ & $\begin{array}{l}2.95 \\
0.47\end{array}$ & $\begin{array}{l}1 \cdot 64 \\
0 \cdot 31\end{array}$ & $\begin{array}{l}1 \cdot 33 \\
0 \cdot 22\end{array}$ & $\begin{array}{l}6 \cdot 72 \\
1 \cdot 00\end{array}$ & $\begin{array}{l}6 \cdot 64 \\
0 \cdot 83\end{array}$ \\
\hline
\end{tabular}

TABLE IV

Significance of Results

\begin{tabular}{l|c|c}
\hline & $\mathrm{t}$ & Probability \\
\hline FEV $_{1}$ & 1.82 & $0.1>\mathrm{p}>0.05$ \\
FRC & 1.06 & $0.5>\mathrm{p}>0.2$ \\
RV & 2.68 & $0.02>\mathrm{p}>0.01$ \\
TLC & 0.20 & $\mathrm{p}>0.5$ \\
\hline
\end{tabular}

this may result in their being liable to experience further attacks of asthma if the appropriate stimuli required to trigger off an attack are encountered.

Of interest is the finding of raised values of $\mathrm{RV}$ in the majority of these patients, in association with a normal $\mathrm{FEV}_{1}$. Briscoe (1965) has pointed out that the important effect on lung volume of obstructive airway disease is that the RV is increased in absolute amount above its predicted value. Cotes (1968) has remarked on the apparently irreconcilable findings of increased RV without an associated rise in airway resistance, and work by Gough (1952) has shown that no permanent anatomical changes occur in asthma, which could account for the raised RV. The observations of Tammeling, Berg, and Sluiter (1966) may shed some light on this. By examining spirograms, they found that there was little change in the $\mathrm{FEV}_{1}$ until after FRC level was reached, when constriction became obvious. High transmural pressures applied during forced expiration could, by causing premature collapse of small peripheral air passages, lead to an increase in RV without affecting the $\mathrm{FEV}_{1}$.

The length of time after cessation of symptoms for which these abnormalities persist is at present uncertian. The present series shows that one individual free of symptoms for 20 years has retained a considerable increase in $R V$, and one 16 years after his last attack has a high lability index. It is possible that abnormalities may persist for the rest of the individual's life.

I wish to thank Professor J. D. Hay for making available to me the facilities of the Department of Child Health, Dr. R. S. Jones for advice and encouragement throughout this work, Professor C. A. Clarke for permission to study his patients, and Mrs. S. Dulson for technical assistance.

This work was supported by a Research Fellowship from the Department of Child Health, University of Liverpool, augmented by a grant from the Children's Research Fund.

\section{REFERENCES}

Barr, L. W., and Logan, G. B. (1964). Prognosis of children having asthma. Pediatrics, 34, 856.

Blackhall, M. I. (1969a). The effect of age on ventilatory function in asthma. M.D. Thesis, University of Aberdeen.

- (1969b). The effect of age on fixed and labile components of airways resistance in asthma. In the press.

Briscoe, W. A. (1965). Lung volumes. In Handbook of Physiology, Section 3, Respiration, Vol. 2, p. 1345. Ed. by W. O. Fenn and H. Rahn. American Physiological Society, Washington, D.C.

Buffum, W. P., and Settipane, G. A. (1966). Prognosis of asthma in childhood. American fournal of Diseases of Children, 112, 214.

Bullen, S. S. (1929). Some observations on the natural history of asthma in childhood. New York State fournal of Medicine, 29, 545.

Cotes, J. E. (1968). Lung Function: Assessment and Application in Medicine, 2nd ed., p. $369 . \quad$ Blackwell, Oxford.

-, Rossiter, C. E., Higgins, I. T. T., and Gilson, J. C. (1966). Average normal values for the forced expiratory volume in white Caucasian males. British Medical fournal, 1, 1016.

Gilson, J. C., and Hugh-Jones, P. (1949). The measurement of the total lung volume and breathing capacity. Clinical Science, 7, 185.

Gough, J. (1952). Discussion on the diagnosis of pulmonary emphysema. Proceedings of the Royal Society of Medicine, 45, 576 . 
Jones, R. H. T., and Jones, R. S. (1966). Ventilatory capacity in young adults with a history of asthma in childhood. British Medical fournal, 2, 976.

Jones, R. S. (1966). Assessment of respiratory function in the asthmatic child. British Medical fournal, 2, 972.

Ogilvie, A. G. (1962). Asthma: a study in prognosis of 1,000 patients. Thorax, 17, 183.

Pearson, R. S. B. (1958). Natural history of asthma. Acta Allergologica, 12, 277.

Rackemann, F. M. (1932). Asthma. XVI Two hundred and thirteen 'cured' patients followed up four years later. Archives of Internal Medicine, 50, 819.

-, and Edwards, M. C. (1952). Asthma in children: a follow-up study of 688 patients after an interval of 20 years. Nerv England fournal of Medicine, 246, 815.

Ryssing, E. (1959). Continued follow-up investigation concerning the fate of 298 asthmatic children. Acta Paediatrica, 48, 255.
- and Flensborg, E. W. (1963). Prognosis after puberty for 442 asthmatic children examined and treated on specific allergologic principles. Acta Paediatrica, 52, 97.

Strang, L. B. (1959). The ventilatory capacity of normal children. Thorax, 14, 305.

Tammeling, G. J., Berg, W. C., and Sluiter, H. J. (1966). Estimation of the expiratory collapse of the intrathoracic airways. American Review of Respiratory Diseases, 93, 238.

Unger, L., Unger, A. H., and Wolf, A. A. (1952). Bronchial asthma in children: treatment and results. Annals of Allergy, 10, 574.

Correspondence to Dr. M. I. Blackhall, Department of Child Health, Royal Children's Hospital, Herston, Brisbane, Queensland 4029, Australia. 